\title{
Using Effective Strategies for Errors Correction in EFL Classes: A Case Study of Secondary Public Schools in Benin
}

\author{
Sourou Corneille Teba \\ ${ }^{\prime}$ University of Abomey-Calavi, Republic of Benin
}

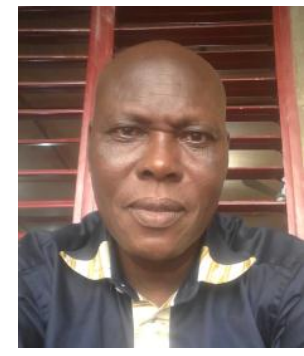

\begin{abstract}
The aim of this paper is firstly, to make teachers correct thoroughly students' errors with effective strategies. Secondly, it is an attempt to find out if teachers are interested themselves in errors correction in Beninese secondary schools. Finally, I would like to point out the effective strategies that an EFL teacher can use for errors correction as far as EFL teaching/ learning is concerned. The results from the interviews and classroom observation will also be taken into account to analyse with problem solving strategies. Field survey is used and the target population was teachers and students in Beninese secondary schools.
\end{abstract}

Keywords: Strategies, Errors, Correction, EFL classes.

Citation | Sourou Corneille Teba (2017). Using Effective Strategies for Errors Correction in EFL Classes: A Case Study of Secondary Public Schools in Benin. Journal of Education and e-Learning Research, 4(2): 63-71.

History:

Received: 18 April 2017

Revised: 6 July 2017

Accepted: 17 August 2017

Published: 7 September 2017

Licensed: This work is licensed under a Creative Commons

Attribution 3.0 License (oc))

Publisher:Asian Online Journal Publishing Group
Funding: This study received no specific financial support

Competing Interests: The author declares that there are no conflicts of interests regarding the publication of this paper.

Transparency: The author confirms that the manuscript is an honest, accurate, and transparent account of the study was reported; that no vital features of the study have been omitted; and that any discrepancies from the study as planned have been explained.

Ethical: This study follows all ethical practices during writing.

\section{Contents}

1. Introduction

2. Method

65

3. Summary of the Results 66

4. Discussion

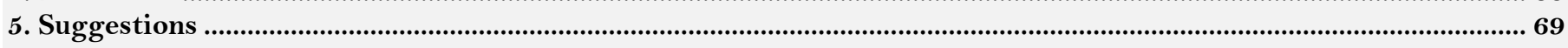

6. Conclusion 71

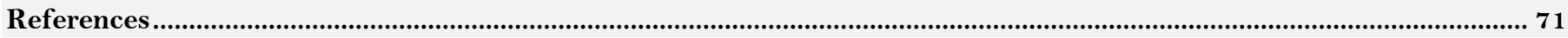




\section{Introduction}

Language teaching requires methodologies and techniques among which EFL teachers are supposed to choose so as to be sure that they know why they are doing what they are doing. In this case, they must be trained to choose among the options that exist in the teaching methodology. The choices teachers make become better when they provide learners with improved access to English learning and their errors' correction.

As far as errors' correction is concerned, Hornby et al. (2009) states that an Error is "a more formal way of saying mistake, especially one that causes problems or affects the result of something. Its synonyms are inaccuracy, slip, howler and misprint" while Correction is "a change that makes something more accurate than it was before." In the linguistics field, Error is a disrespect of the language set of rules that are grammatically confessed correct. The role of linguists here is very important due to the fact that linguists study languages and write most of the students' books in EFL teaching/learning. Moreover, EFL learners are evaluated and tested on the basis of the activities in those books. That is the reason why this latter definition is suitable for my research.

Moving from this it is necessary that EFL teachers use a combination of sensitive errors-corrections strategies and practice so as to increase their learners' interlanguage (intermediate between native language and target language). Hence, EFL teachers are obliged to correct EFL learners' errors in order to improve and motivate EFL learning. He/ She should make students love the target language and even speak it easily as their mother tongue or native language. At this point, creating a friendly and secure classroom atmosphere is determinant to a maximum interaction among students themselves, and students and teacher.

Furthermore, I have noticed that EFL teachers are still faced with the problem of "which errors to correct" and "how to correct errors". There is also a remark that in Beninese EFL classes, the strategies used by the EFL teachers for errors-correction are not the convenient and effective one. They have to lead their learners beyond their errors; but unfortunately some learners are demotivated while others consider EFL Learning as a difficult task and abandon classes due to this.

The aims of my research are to shed light on the causes and the places of errors in the process of EFL teaching/learning in my country. Then, I try to show how important it is to use effective strategies for errors correction in EFL classes.

\subsection{Background of the Paper}

Using Effective Strategies for Errors Correction in EFL Classrooms: A Case Study of Some Secondary Public Schools in Benin is not a topic chosen at random. This comes from the fact that I have noticed many publications about E.F.L/E.S.L teaching methodology books, teaching programmes, theoretical research, etc...And many of the latter emphasize most on the importance of an authentic, motivating and cognitively appropriate treatment in the field of T.E.F.L. But, while considering errors/ mistakes as part of almost all learning process, mainly in T.E.F.L, there is a need to focus on the strategies for its correction. Thus, I have noticed in Beninese secondary schools that different strategies for errors correction are being used; and having been an E.F.L learner before becoming E.F.L teacher, I would like to denounce some strategies that demotivate while other encourage: for example, every time punishment and mockery cannot motivate as it is clearly known that teachers' role is to guide learners but also to correct learners shortcoming in such a way to increase their love for the language mainly in beginners' classes. So, in order to teach English successfully, E.F.L teachers should use effective strategies for errors correction.

Another reason is that during my first contact with English language in the first form of junior secondary school, I was confronted with a certain number of difficulties with regard to phonetics, syntax and semantics issues. Indeed, like the E.F.L learners of my age, I had anticipated taking pre-training lesson during the holidays courses as soon as I left primary schools. But, once in contact with English language, I found numerous difficulties to acquire only the correct forms of what I was taught. Some of these difficulties lead me to make mistakes related to: vocabulary, tense:

Moreover, I still remember that when I made mistakes/errors I was punished mainly for making a lot of mistakes. This implies that errors/mistakes should be avoided. Then, for fear of making mistakes and hence be punished, I decided to keep quiet whatever the question is in order not to be punished. Likewise, success of a language course reflects the teachers' professional practice or scientific knowledge because the aim of EFL teachers while teaching the language is to enable their students to communicate fluently in good atmosphere. In the contrast, when the learners find the learning situation very difficult, the beginners dare not utter a simple sentence to ask or to answer question; they fail to participate actively in free conversation activities because they have great difficulty to understand what is being said.

A further reason which accounts for the need to carry this paper has to do with the fact that some EFL teachers do understand the importance of errors correction, but they lack strategies needed and fail to know very well how to engage in. They also forget that repetition is pedagogic and allow students to have an eye upon the frequent errors/ mistakes they make. Most of the teachers do not take into account the result of their correction and use the outcomes to teach students about their mistakes/ errors. This leads to the fact that the students repeat the same errors since they have not been so involved in the correction of those errors/ mistakes they did.

The detailed examinations of these contradictory attitudes allow me to consider that there are some gaps as far as strategies for learner's errors correction are concerned, but also it results from my desire to show the importance of the strategies while dealing with errors correction in a classroom situation. Taking into account the above remarks, what interests can this work have for teachers and learners?

\subsection{Purpose of the Study}

Though the first aim of learning language is to speak it, to make oneself understood and be accepted in the ethnic group, errors correction also helps to master the language and enjoy all the benefits the language offers in the field of communication, written information, reading books, listening to news, writing or reading letters or messages, knowing the content of some notice etc... That is why at school, EFL teachers usually test their students on the basis of the learning skills improvement. The teachers' objective is to make their students speak, listen, read 
and write without making mistakes and errors. But, on the contrary, many students neglect all these notions and make errors.

The aim of this paper is firstly, to make teachers correct thoroughly students' errors with effective strategies. Secondly, it is an attempt to find out if teachers are interested themselves in errors correction in Beninese secondary schools. Finally, I would like to point out the effective strategies that an EFL teacher can use for errors correction as far as EFL teaching/ learning is concerned.

\subsection{Research Questions}

My study aims at finding answers to the following questions:

1. What are the challenges faced by EFL teachers why correcting errors in classes in Benin?

2. How can the EFL teaching/learning be improved through errors correction?

3. What are the effective strategies used as approaches of solutions to correct errors in EFL classes?

\subsection{Significance of the Study}

Using effective strategies for errors correction in EFL classes is the key concept under exploration in this paper. Such an exploration is important because it paves the ways for EFL teachers to cope with their learners' difficulties. Thus, It helps them forecast the possible difficulties and weaknesses of their students due to the ineffectiveness of the strategies they use to correct errors made by the latter in Beninese public secondary schools. They will also learn from this paper and draw from it strategies to turn their learners' weaknesses into linguistic competences.

This study is significant since it helps the EFL teachers gather solutions to overcome those difficulties related to errors correction strategies. I can mention as illustration that considering errors as a sign of failure, many teachers use to reprimand EFL learners for almost all their errors. So, in order to avoid being blamed, EFL learners hesitate or even refuse to practice the language. Some of them even have abandoned EFL classes. It is then undoubtedly clear that some errors correction strategies can be described as defensive.

This study is relevant because it sheds light on the role of the teachers' job which is to guide learners but also to correct their shortcomings. So, it is then important that teachers know the effective strategies of errors correction. These strategies may not be the same from an area to another and from one teacher to the other. It is then necessary for EFL teachers to find other errors correction strategies to motivate learners.

\section{Method}

In order to have reliable information, I have used both quantitative and qualitative research methods. The quantitative method deals with documentary research whereas qualitative method deals with classroom observation and students' interviews. I have used well-structured questions in accordance with the purpose of the study which is to identify if teachers are interested themselves in EFL learners' errors correction in the secondary schools.

\subsection{Research Population and Sample}

The purpose of this study is to make EFL teachers correct thoroughly students' errors with effective strategies. Therefore, EFL teachers and learners are primarily concerned with this study. Although all the actors are concerned with this study, I have sampled eighty teachers (80) and five hundred and thirty-four learners of the first cycle that is from form 1 (6è) down to form 4 (3è). Their answers to my questionnaires allowed me to get reliable and accurate information in the field. The following table gives a summary of the research population.

Table Research population and Sample

\begin{tabular}{|c|c|c|c|c|}
\hline $\mathrm{N}^{\circ}$ & Areas & Schools & Number of teachers & Number of Learners \\
\hline \multirow[t]{2}{*}{1} & \multirow[b]{2}{*}{ PLATEAU } & CEG 1 Ifangni & O3 & 27 \\
\hline & & CEG Igolo & $\mathrm{O} 2$ & 14 \\
\hline \multirow[t]{2}{*}{2} & \multirow[t]{2}{*}{ OUEME } & CEG Davie & 05 & 23 \\
\hline & & CEG Ekpe & O3 & 30 \\
\hline \multirow[t]{2}{*}{3} & \multirow[b]{2}{*}{ ATLANTIQUE } & CEG1 Abomey calavi & O4 & 30 \\
\hline & & CEGToffo & O4 & 20 \\
\hline \multirow[t]{2}{*}{4} & \multirow[t]{2}{*}{ LITTORAL } & CEG Akpakpa & 05 & 30 \\
\hline & & CEG Vedoko & O4 & 25 \\
\hline \multirow[t]{2}{*}{5} & \multirow[t]{2}{*}{ MONO } & CEG Come & O3 & 20 \\
\hline & & CEG Grand popo & O3 & 25 \\
\hline \multirow[t]{2}{*}{6} & \multirow[t]{2}{*}{ COUFFO } & CEG 2 Lokossa & $\mathrm{O} 2$ & 20 \\
\hline & & CEGDogbo & $\mathrm{O} 2$ & 20 \\
\hline \multirow[t]{2}{*}{7} & \multirow[t]{2}{*}{$\mathrm{ZOU}$} & CEGBohicon & O4 & 20 \\
\hline & & CEG Abomey & 05 & 20 \\
\hline \multirow[t]{2}{*}{8} & \multirow[t]{2}{*}{ COLLINES } & CEG1Savalou & O3 & 25 \\
\hline & & CEGDassa & O4 & 25 \\
\hline \multirow[t]{2}{*}{9} & \multirow[t]{2}{*}{ ALIBORI } & CEGN'Dali & $\mathrm{O} 2$ & 20 \\
\hline & & LYCEE Mathieu Bouke & O4 & 20 \\
\hline \multirow[t]{2}{*}{10} & \multirow[t]{2}{*}{ BORGOU } & CEGTitirou & O3 & 20 \\
\hline & & CEGKandi & 03 & 20 \\
\hline \multirow[t]{2}{*}{11} & \multirow[t]{2}{*}{ DONGA } & CEG1 Djougou & O3 & 20 \\
\hline & & CEG2 Djougou & $\mathrm{O} 2$ & 20 \\
\hline \multirow[t]{2}{*}{12} & \multirow[t]{2}{*}{ ATACORA } & CEGNatitingou & 05 & 20 \\
\hline & & CEGMateri & $\mathrm{O} 2$ & 20 \\
\hline \multicolumn{2}{|c|}{ Total } & 24 & 80 & 534 \\
\hline
\end{tabular}




\subsection{Instruments of Investigation}

\subsubsection{Questionnaire Addressed to Teachers}

This research instrument is addressed to EFL teachers in Benin Secondary Public schools especially those sampled for the investigation.

The objective of the questionnaire is to get the teachers' opinion on the topic. It is described as follows:

\subsubsection{Questionnaire Addressed to Learners}

This instrument is addressed to EFL learners in Benin Secondary schools especially those sampled for the investigation.

The objective of the questionnaire is to get the learners' opinion on the topic. It is described as follows:

\subsubsection{Teachers' Interviews}

I have designed a few pre-set questions and interviewed one hundred (100) target teachers who have some experiences in their teaching field. I have met them in their different schools. A sample of those pre-set questions can be described as follows:

\subsubsection{Classroom Observations}

Through my investigation, I have observed five (5) English classes. Through classroom observations, I intended to find more relevant and reliable information about what errors EFL learners make, how often they make those errors, how and when EFL teachers correct them and finally observe their attitudes toward their teachers' errors strategies. Furthermore, classroom observations have helped me to notice the techniques teachers use to avoid being out of themselves when they are faces with learners' bad attitudes about some errors' correction strategies, and they do most to succeed in learners' errors correction.

All of my questionnaires used as drawn in line have been shown to my research's supervisor, to vet the structuring, adequacy and content validity of the items. Based on her expert's suggestions, some of the items were reworded, restructured, and others deleted. And through this press, both content and face validity of the questionnaires were achieved.

\subsection{Data Collection and Method of Analysis}

The data I have collected through the uses of various tools are organized, classified and tabulated before they can serve any worthy while purpose.

A coding scheme was prepared and the data presentation has been done through a number of statistical computation tables used to illustrate the data where appropriate.

\subsubsection{Data Collection}

The method of data collection for this study focused on designed questionnaires to learners and teachers, interviews and classroom observations. I distributed questionnaire sheets to learners. This distribution was made possible on the agreement of school authorities and teachers in command of the different classes. Once in the classroom I greeted the teacher and learners, then I informed them about the objectives of my visit and explained what the questionnaire is about. Then, I distributed the questionnaire sheet to my respondents. When they finished answering, I collected them on the spot. This technique helped me to get back $100 \%$ of the students' questionnaire. As far as teachers' questionnaire is concerned, I interviewed them, then I distributed the questionnaire to them and let them go back home in order to provide adequate and careful answers and bring them back for the following weekly session. The classroom observations were done according to a well-planned program with both the vice-principal and the selected teachers.

\subsubsection{Method of Analysis}

The data I have collected through the uses of various tools are organized, classified and tabulated before they can serve any worthy while purpose.

A coding scheme was prepared and the data presentation has been done through a number of statistical computation tables used to illustrate the data where appropriate.

\section{Summary of the Results}

\subsection{Summary of Students Results}

- $98.5 \%$ of the respondent learners said they make regularly errors during EFL learning process whereas $1.5 \%$ of them said the opposite.

- 22, $47 \%$ of the respondents said they make errors during speaking process; $23,40 \%$ of them make errors during reading process; $41.74 \%$ of the learners said they make errors during writing process and finally $12,40 \%$ of the respondent learners said they make errors during listening process

$-90.36 \%$ of the respondent learners do not like the way their teachers' correct errors whereas09.64\%of them believe it.

- $32 \%$ of the respondent do not like their teachers' way in correcting errors because they interrupt them; $12 \%$ of them said that he/ she shouts at them in correcting errors; $2 \%$ of them said that he/she makes them feel hopeless in making errors/ mistakes whereas $54 \%$ of them do not like their teachers' way in correcting errors/ mistakes because they make them afraid of speaking.

-The entire respondent $(100 \%)$ confessed that during EFL learning process they make errors related to verb tense, word order, omission of article, subject-verb agreement, pluralized adjectives, pronunciation, intonation, word stress, sentence stress, syllable omission, incorrect use of word collocation and incorrect use of function.

- $45 \%$ said they want to be corrected through their teachers' repetition in the class; $44 \%$ of them want to be corrected through a review at the end of class; $43 \%$ prefer errors' correction through feedback or homework 
correction before starting a new teaching class, $42 \%$ said that they want to be corrected through their teacher's personal correction with me, $32 \%$ like errors correction through pair work and small group work and only $12 \%$ said they want to be corrected through English quiz, testing or evaluation paper's marking and finally

$-84.5 \%$ of the learners said their teachers' attitudes are very important and finally $15.5 \%$ think that their teachers' attitudes are not important at all.

\subsubsection{Students' Suggestions to the Problems}

The majority of the learners have suggested that:

- They would like to be corrected during EFL class through authentic materials as far as listening and speaking skills are concerned.

- They want their teachers to consider their level before marking their papers.

\subsection{Summary of Teachers Results}

\subsubsection{Learner's Errors through Learning Skills}

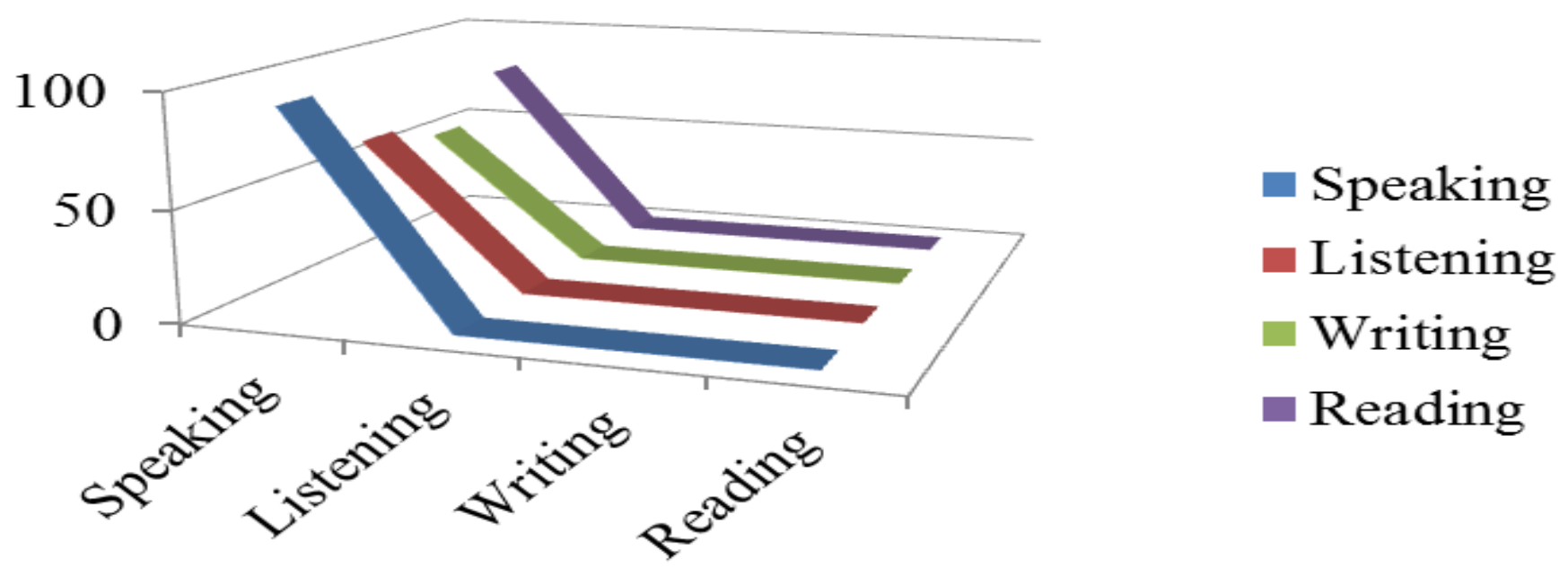

Through these answers, $93 \%$ of the respondent said that most of the time their learners make errors during speaking activities, $79 \%$ of them said learners make errors during reading, $66 \%$ of the teachers said that their learners make errors during listening activities whereas $57 \%$ of them said that they make errors during writing activities.

$-10.64 \%$ of the respondent teachers said that lack of motivation or carelessness is one of the causes of learners' errors; $36.17 \%$ of them said that learners' errors are also due to their social environment; $12.76 \%$ of the teachers said that teachers' translation word by word of idiomatic expression is another cause of learners' errors; $10.63 \%$ of the teachers said that lack of the teachers' knowledge about learners'L1 and of the target language comparison is a cause of learners' errors;

$09.57 \%$ of them agreed that intralingua interference, the difficulty or the problem of the language itself is a cause of learners' errors and $07.44 \%$ of them

said that EFL teachers' comparison of learners' L1 and of the target language is one of the causes of learners' errors; none $(0 \%)$ of the respondent teachers do not agree that L1 interference, language transfer or interlanguage interference can be a cause of learners' errors.

- $76 \%$ of the respondent teachers said that their learners like to be corrected whereas $(24 \%)$ of them said the opposite.

$-51.06 \%$ of the respondent teachers do not have any knowledge about learners' errors correction; $41.48 \%$ of the teachers think about their learners' educational history; $05.31 \%$ of them think about learners' learning styles and finally $02.12 \%$ of the respondent teachers said that they think about both their learners' skill level and educational background.

$-27.65 \%$ of the teachers said that they do individual correction during group or pair work; $54.25 \%$ of them said that when hearing an error, they stop the learner and make him/her say it correctly; $13.83 \%$ of them said that they encourage peer correction or have students correct each other; $4.26 \%$ of the teachers said that they notice points that everyone gets wrong, and deal with them later at the end of the activity segment.

$=51.06 \%$ of the respondent said that they do immediate correction for pronunciation or grammatical error; $12.76 \%$ of the delay correction for communication purposes and $36.17 \%$ of them said that they only correct errors / mistakes through English quiz and evaluations papers marking.

$-50 \%$ of the respondent teachers said that their goal in correcting learners' errors is to help them speak or write in a grammatically correct manner; $26.59 \%$ of them would like to help learners speak quickly and smoothly without much thought while correcting them and finally $23.41 \%$ of the respondent teachers would like to keep a good balance of fluency and accuracy in correcting learners' errors/ mistakes.

$-37.23 \%$ of the respondent teachers said that they have difficulties in correcting learners' errors or mistakes because they lack of mastery of the strategies for errors' correction; $29.78 \%$ of them they lack of training about the effective strategies for learners' errors correction; $20.22 \%$ of them said that fear of not being able to finish the program hinders learners' errors correction and finally $12.76 \%$ of them said that they lack of time in correcting learners' errors.

\subsection{Interviews}

The first remark is that the interviewees were very kind and accepted to help me kindly. Most of them confessed that correcting effectively beginners' errors/mistakes is not an easy task while taking into account the 
four learning skills. Secondly, they have been teaching EFL for many years without mastering the strategies for errors' correction as far as classrooms' activities are concerned. The reason for this situation according to them is that they lack of training about the effective strategies for learners' errors correction. Finally, all of them asserted that effective teaching/learning is closely linked to the mastery of the strategies of errors' correction.

\subsection{Classroom Observations}

This research instrument has helped me visit and observe five colleagues during classroom situation in order to notice the types of activities in process, the categories of errors made by learners, teachers' attitudes towards errors and finally the possible causes and impacts of the teachers' errors correction strategies on E.F.L teaching/learning.

These are my remarks at the end:

In three of these classes function and structure activities were carried out whereas reading, writing and vocabulary activities were carried out in the others. During these activities, I have noticed many categories of errors made by learners such as verb tense, word order, pronunciation, subject-verb agreement, incorrect use of function etc. Face to such errors, four (4) teachers got angry and felt like giving up teaching. So they insult, shout and blame learners for making mistakes/errors before correcting them. As consequence, those errors refrain or participate no more until the end of the class session. But the fifth teacher discouraged on the contrary those who was insulting and laughing at the one make error. He encouraged then the learner who has made error/mistake and made him gently repeat the correct form.

At the end of my observations, I had the opportunity to discuss the causes and impacts of teachers' attitudes towards errors correction in E.F.L classes. During this conversation, some of the E.F.L teachers confessed that they hate errors; other said they were not aware of effective strategies for errors correction; for other, it is a matter of self- controls but some other raised the problem of large class size.

\section{Discussion}

The data I have collected from questionnaires, classroom observations and interviews revealed some important points from Beninese EFL teachers and learners which should be discussed. In this section, I will deal with problems teachers have while doing their teaching job, the factors that prevent teachers from correcting students' errors efficiently and the impacts of errors correction on E.F.L teaching/learning.

\subsection{Problems Teachers have while doing their Teaching Job}

The data I have collected reveals that EFL teachers involved in my research work do not have experience enough in teaching English as Foreign Language. Thus, the majority of them (28.72\%) have been teaching English for four years. This lack of experience obliges them to mistreat students' errors. That means they do not use appropriate strategies to correct learners' errors.

The results have also helped me to notice that seventy percent of E.F.L teachers have been doing the job without any professional qualification. Only six percent of them are professionally trained with BAPES and CAPES. This clearly shows that the great majority of E.F.L teachers lack the appropriate techniques and strategies which will allow them to deal with learners' errors correction accordingly. It can be concluded that the Benin educational system is suffering from lack of qualified teachers to do the job with confidence. Indeed, this lack of qualified teachers in Beninese secondary schools' authorities are obliged in this conditions to recruit teachers holding academic qualifications such as LICENCE and MAITRISE as part time teachers. Moreover, the problem of unemployment has also led to a lot of young people to the teaching field without any vocation forgetting that teaching is not an easy job or way out. In this vein, Kochar and Deshpande (1985) asserts that: "teaching is not a soft option. It is more than standing before a class and applying a few specific techniques. It is not merely presenting textbook information and then testing student's ability to repeat it”. In the same trend, Edward (1967) an eminent educationist, explains that: "pouring out knowledge is not teaching. Hearing lessons is not teaching... Teaching is getting at the heart and mind so that the learner begins to value learning, and to believe that learning is possible in his own case". For him, teaching requires the abilities to produce a positive change in learners as regard to the knowledge they are supposed to acquire. This shows that teaching is not an easy job and teachers need to be trained before starting teaching so as to correct E.F.L learners' errors accordingly.

\subsection{Factors that Prevent E.F.L Teachers from Correcting Learners' Errors Efficiently}

When I refer to the results of data collected, I remark that there are many factors that lead to wrongly correct E.FL learners' errors. Thus the main cause of this issue is the lack of teachers' pre-service training. In fact, ninetyfour percent of E.F.L teachers involved in this study are untrained and only six percent of them are trained. Considering this results, it is clear that E.F.L teachers are not equipped with effective strategies which would allow them to deal with learners' errors correction efficiently. It can be deduced from this results that teachers preservice training is very important for E.F.L teachers because it offers them the necessary basic teaching skills they need to perform well or to be effective in their classes. In order to show the importance of a prior training for a teacher, Tamakloe et al. (2005) argues that "teaching is closely associated with training". That is to say that teaching cannot be effective if the teacher has not been trained beforehand. In the same trend, Aggarwal (2007) states: "It is generally observed that a teacher with training becomes more mature confidently". But unfortunately, it is not the case in Beninese secondary schools. It is then important to notice that the teaching/learning process will surely lack effectiveness since those teachers who are supposed to improve it are not skilled. This certainly leads, Aggarwal (2007) to affirm: "through training, the future teacher becomes familiar with the methodology of teaching. He also gets essential knowledge of methods required for a particular subject. He teaches with flair and not in a routine way". So a teacher without prior training is incomplete as he will not be skilled enough to correct learners' errors accordingly.

Another factor that prevents E.F.L teachers from dealing efficiently with learners' errors is large class size. According to the results from classroom observations, the average number of students in E.F.L classes is sixty and the most crowded classes have seventy students. This situation can be explained by the fact that there are more 
students than classrooms in Beninese secondary schools. In this kind of classrooms, the teacher would find it difficult to use the effective strategies as far as learners' errors correction is concerned.

In addition, some E.F.L teachers having in their mind how to manage to finish the program mainly in forms 1and 4 ignore the right way of correcting students' errors. In other words, these teachers just correct learners' errors by stopping them thinking that this way will help them gain time. But, this is not without consequences

\subsection{Negative Impacts of Errors Correction on EFL Teaching/Learning}

The results of my investigations show that errors' correction has negative impacts not only on teaching/learning process but also on students' academic performance. Errors should be regarded as a necessary part of learning a language; but the way EFL teachers correct them would prevent this objective from being reached. In fact, the majority of students (54\%) involved in this work confessed that their teachers insult or shout at them when they make mistakes. This attitude from those teachers is not encouraging learners to develop good habits towards English language learning. They should know that errors are very important in English language learning for communicative purpose. Therefore, teachers should use appropriate strategies to correct their students' errors if they want to develop that skill in them. Moreover, this lack of effective strategies using to correct learners' errors creates reluctance in students. In other words, these students would become shy and would not participate actively in the classes activities. In this condition, the process of teaching/learning will be ineffective since the teacher's objective which is to encourage communication (speaking) in their classes will not be reached.

\section{Suggestions}

\subsection{EFL Teachers' Attitude to Errors}

EFL teachers should not be afraid when their students are making errors. Some EFL teachers feel that students might learn their mistakes and so they must make sure that everything they say is correct. This attitude is not good and goes back to the earlier belief, influenced by the behaviorist model of learning, which maintains that the language can be learnt by repeating correct forms until they become automatic, that is why repeating incorrect forms is harmful. It is now widely agreed that language is not learnt this way: it is a system of rules that the learner has to acquire, that trying out language and making errors are natural and unavoidable parts of this process. Adrian (1993) explains that learners are applying rules from their own first languages and they are applying rules which they have internalized but they are in some way intermediate between their native languages (L1) and the target language (L2).

In addition to the matter of activity instruction there are some teachers' behaviors. EFL teachers should know that their learners fell angry when correcting his/ her mistakes too much. Wright (1976) expresses what follows: "Too much correcting of a student's mistakes or errors may discourage him." This simply means that E FL teachers should only correct the learners' serious error through repetitions. By so doing, he/ she will bring the learners participate in English classes.

Another element of E.F.L teachers' behavior is humiliation. In a word, humiliation and insults must be avoided because they lead the learners to have feeling of inferiority and this can generate their dislike of the language. E.F.L teachers should not humiliate their learners by telling them that they are not good. Because, they may not be genuinely interested in his/ her courses; they may not also be showing any respect to him/ her and they will just consider the English lessons as an empty thing.

In order to have a good attitude about EFL learners' errors correction, EFL teachers must know learners seating in front of them. They should know the different learners, their origins, their problems in real life. When this fact is observed in the class, learners feel comfortable and confident to their teacher and can easily be corrected. This approach is not something to neglect. When it is combined with the other teaching dimensions such as Academic and methodological dimensions, teaching become very pleasant and both teachers and Learners are no more confused but show interest in the teaching and learning process. They interact well and learn from each other. It is up to us teachers to make an effort to practice this method as a tool for teaching, correcting errors/ mistakes and marking papers. Based on all above, it can be said that EFL teachers need to know their students/ learners seating in front of them to avoid frustrating them in some ways since they come from different areas with different problems.

\subsection{Kinds of Errors to be corrected}

Learners' errors are usually classified in different categories. Burt (1975) made a distinction between "global" and "local" errors. Global errors hinder communication and they prevent the learner from comprehending some aspects of the message. Local errors only affect a single element of a sentence, but do not prevent a message from being heard. According to Hendrickson (1980) global errors need not be corrected and they are generally held true. But the expressions such as "a news" or "an advice" are systematic errors, and they need to be corrected. As for presystematic errors, teachers can simply provide the correct one. For systematic errors, since learners have already had the linguistic competence, they can explain this kind of errors and correct them themselves. So teachers just remind them when they commit such errors. As to what kind of errors should be corrected, it needs teachers' intuition and understanding of errors. At the same time, EFL teachers should consider the purpose of correcting EFL learners' errors that is to have a good balance of accuracy and fluency.

EFL teachers should know that when they use effective strategies for their learners' errors correction, when it "works", it does so by helping the learner change his or her conscious mental representation of a rule. In other words, it affects learned competence by informing the learner that his or her current version of a conscious rule is wrong. Thus, EFL learners' errors should indeed be corrected (but not at all times; see below; and not all rules, even if the goal is learning). 


\subsection{EFL Teachers' Strategies for Learners' Errors Correction}

Concerning this problem, the most controversial issue is to treat errors immediately or to delay. First, we are confronted with a dilemma-fluency versus accuracy. For communicative purpose, delayed correction is usually preferred.

EFL teachers should be aware that when to correct errors is determined by the type of errors committed. For instance, if they are pronunciation or grammatical errors, immediate correction is preferable, for post-correction cannot make learners remember anything. Furthermore, the overall situation in the classroom is also important. When the whole class is familiar with a word, but only one of them is singled out for being corrected, he or she would feel awkward. So, when to correct is very complicated. Both the teachers' intuition and the feedback from the learners are equally important.

\subsection{Principles of EFL Learners' Errors Correction}

According to James (1998) in order to correct effectively EFL learners' errors, EFL teachers should follow the three principles in error correction: Firstly, his/ her techniques involved in error correction would be able to enhance the students' accuracy in expression. Secondly, the learners' affective factors should be taken into consideration and the correction should not be face-threatening to the students, but it should be indirect correction. EFL teachers should encourage students to do self-correction in heuristic method or present the correct form, so they couldn't feel embarrassed.

Let us compare the two situations below:

(1) Student: "What means this word?

Teacher: "No, listen, what does this word mean?"

(2) Student: "What means this word?"

Teacher: "What does it mean? Well, it is difficult to explain, but it means...

It is obvious that teacher's remodeling in (2) is more natural and sensible than the direct interruption in (1).

\subsection{Dissimilar Ways of EFL Learners' Errors Correction}

There are several ways of correction that can be employed in the classroom.

- Self-correction: After the student recognizes what is incorrect in his/her response, he/ she should be able to correct himself/herself. Self-correction is the best technique, because the student will remember it better.

- Peer correction: If the student cannot correct himself/ herself, the teacher can encourage other students to supply correction. This technique is to be applied tactfully, so that the student who originally made the mistake will not feel humiliated.

In the case of errors, it is useful if after peer correction the teacher goes back to the student who made the error and gets him/her to say it correctly.

According to Edge (1990) peer correction has the following advantages:

- It encourages cooperation, students get used to the idea that they can learn from each other;

- Both learners (who made the error and who correct) are involved in listening to and thinking about the language;

- The teacher gets a lot of important information about the learners' ability - if students learn to practice peer correction without hurting each other's feelings, they will do the same in pair-work activities.

However, it may happen that whenever the teacher asks for peer correction from the whole class, it is always the same students who answer. In this case the teacher has to make sure that other students are involved as well.

- Teacher correction: If no one can correct, the teacher must realize that the point has not yet been learnt properly. In that case the teacher can re-explain the problematic item of language, especially if the teacher sees that the majority of the class has the same problem. There might be more repetition and practice necessary.

EFL teachers must not forget that the main aim of correction is to facilitate the students to learn the new language item correctly. That is why it is important that after correction the teacher has to ask the student who originally made the error or mistake to give the correct response.

\subsection{Learners and Learners' Parents}

The importance of English Club is that it helps learners to improve their listening skills as well as their oral proficiency through some activities such as songs, debates, poems, trips and visits to TV office, films and projections. It is clear that learners who participate effectively in English club activities in his/ her school will not have fear of being corrected in the classroom. So, to extend the speaking ability, learners should search for opportunities. They must consider English classes like other lectures classes. They must also avoid speaking French, Yoruba, Wémègbé, Torigbé, Dendi, Wama, fon ,etc at English classes and realize that whenever they are engaged in the communicative process, they are accepted by their teachers and peers.

In order to have a good balance of accuracy and fluency, EFL learners should take into account the following suggestions.

They should:

- Respect their teachers;

- Behave well in class

- Respect the classroom rules;

- Give themselves to the target language;

- Pay attention to their teachers' correction and the different activities carried out in the class;

- Work hard if they really want to learn English

I cannot finish my suggestions without addressing the learners' parents. 
They should achieve their responsibilities toward their children if they want them to master the English language. So, parents should:

- Be fair with their children;

- Discipline their children at home;

- Supply their children with whatever they need at school;

- Be careful to whatever their children say about the teachers;

- Have regular contact with their children's teacher to know how they are behaving;

- Always control their children behavior;

\section{Conclusion}

Nobody can deny today that the ways teachers correct students' errors or mistakes has either positive or negative impacts on E.F.L teaching/learning. Unfortunately, what I really notice through this study is that most of teachers have problems correcting students' errors in E.F.L classes. In fact, this is a serious problem which should be thought about in order to find adequate solutions to solve it. Indeed, this study is undertaken to make E.F.L teachers correct thoroughly students' errors with effective strategies. It is also meant to point out the effective strategies that a teacher can use for errors correction as far as E.F.L teaching / learning is concerned. To achieve this goal, I have tried to expand my knowledge about the topic under consideration by reading the work of some scholars interested in the difficulties related to the use of effective strategies to correct students' errors and their suggestions to find out solutions to these difficulties.

During my readings, I have noticed that some factors are preventing E.F.L teachers from using appropriate strategies to correct their learners' errors. In fact, I have discovered the lack of teachers' pre-service training as the main cause of this problem. Thus, teachers should be trained before starting teaching since training offers them adequate strategies or techniques which will help them deal with students' errors when they occur. Moreover, I have discovered some types of errors. These are language transfer or interlingua interference, intralingua interference, different learning strategies, lexical error and the psychology of pronunciation errors. I have also found out some causes of students' errors. In fact, I have noticed that carelessness, first language interference and translation are the basic causes of students' errors. During my readings, I have discovered the moment errors should be corrected, the types of errors which should be corrected and the way they should be corrected. Some effective strategies for errors correction have been found out as well. For example, teachers should use delay correction strategy to correct their students' errors. Here, he/she makes a list of students' errors and at the end of the activity he/she will correct them by making the students correct themselves or each other.

To further the development of my study, I have chosen a sample from the population of teachers and students as the main human resources involved in the pedagogical system. In fact, to obtain reliable data, I have distributed questionnaires to one hundred teachers and to two hundred and eighteen students from ten different secondary schools. Interviews and classroom observations were also carried out. This methodology helps me to collect data about my topic.

Indeed, after the analysis of the data collected, it is important to conclude that the majority of E.F.L teachers I have sampled face the problem of errors correction. Thus, they are not experienced enough in English language teaching. In addition, they are doing teaching job without any professional qualification, meaning that they are not trained. Furthermore, this analysis of data clearly shows that errors correction has many causes such as the lack of teachers' pre-service training and the large size classes. In fact, errors' correction creates reluctance in the students and then the teaching/learning process will become ineffective.

In order to solve the problem of errors correction, I have made some suggestions. I have then invited E.F.L teachers to pay attention to their learners' errors and to use adequate strategies to deal with them when they occur. I have also invited students to attend English clubs so that they improve their speaking skill. Moreover, they should avoid speaking native languages in class.

Eventually, I think at this stage of my work that it will not be left without any more improvement from other researchers. Beninese secondary schools need endeavors from all the citizens and I hope that Ihave given my modest contribution through this work. I hope that this piece of work may open new paths for other researchers in the same field.

\section{References}

Adrian, D., 1993. Teach english: A training course for teachers. Cambridge: Cambridge University Press.

Aggarwal, J.C., 2007. Essentials of educational technology innovations in teaching learning. Noida Vikas Publishing House Pvt. Ltd.

Burt, M.K., 1975. Error analysis in the adult EFL classroom. TESOL Quarterly, 9(1): 53-63. View at Google Scholar | View at Publisher

Edge, J., 1990. Mistakes and correction (Longman Keys to Language Teaching). Harlow: Longman.

Edward, T., 1967. Headmaster of Uppingham school; life, diary and letters by Parkin, George Robert, Sir, 1846-1922. London: Macmillan \& Co., Ltd.

Hendrickson, J., 1980. The treatment of written work. Modern Language Journal, 64(2): 216-22 1. View at Google Scholar |View at Publisher

Hornby, A.S., W. Sally and A. Michael, 2009. Oxford advanced learner's dictionary. Oxford, England: Oxford University Press.

James, C., 1998. Errors in language learning and use: Exploring error analysis. London: Longman.

Kochar, S.C. and J.V. Deshpande, 1985. On exponential scores statistics for testing against positive aging. Statis tics and Probability Letters, 3(2): 71-73. View at Google Scholar | View at Publisher

Tamakloe, E.K., F.K. Amedahe and E.T. Atta, 2005. Principles and methods of teaching. Accra: Ghana Universities Press.

Wright, A., 1976. Visual materials for the language teacher. Essex: Longman Wilson. 